\title{
Kansanopistot luupin alla
}

\section{Jukka Määttä \& Pentti Yrjölä (2001). Kansan- opistojen arviointi- raportti "Perinteen ja nykyajan puristukses- sa ". Arviointi 10/2001. OPETUSHALLITUS}

\section{"Perinteen ja nykyajan} puristuksessa" seuraa kolmantena kahta aiemmin toteutettua vapaan sivistystyön viranomaisarviointia. Näistä kansalaisopistojen arviointi tehtiin vuonna 1996 ja opintokeskuksiin kohdistunut arviointi taas vuotta myöhemmin.

Yleisesti voi todeta, että nyt käsillä oleva Jukka Määtän ja Pentti Yrjölän toteuttama arviointi pohjautuu monipuoliseen aineistoon ja on asiantunteva työ. Tulokseen ei voi olla vaikuttamatta molempien tekijöiden kansanopistotoiminnan tuntemus. Raportti on kansanopistokentän näköinen ja esille nostetut ongelmat ja kehityshaasteet toden tuntuisia.

\section{Raportti toimii}

arviointitulostensa lisäksi myös erinomaisena lähdemateriaalina niille, jotka haluavat tutustua kansanopistotoiminnan tunnuspiirteisiin ja viimeaikaisiin kehityskulkuihin.

\section{Raportin materiaali on}

koottu opistoista eri ryhmiin (opiskelijat, opettajat, johtokuntien puheenjohtajat, rehtorit ja talouspäälliköt) kohdistettujen kyselyjen, 15 opistoon tehtyjen vierailujen yhteydessä koottujen haastattelujen ja laajan asiakirja-aineiston avulla.
Taloudellisesti opistojen todetaan selvinneen lamavuosien jälkeen keskimäärin kohtalaisen hyvin. Myös opiskelijaviikkosuoritteilla mitaten kansanopistojen toiminta on korkeammalla tasolla kuin koskaan. Suurimmalta osin tämä selittyy nimenomaan lyhytkurssien suosion voimakkaalla kasvulla. Pitkien linjojen suosio on jonkin verran laskenut parin vuosikymmenen takaisesta huipusta.

\section{Arvioinnin päätuloksena} esitetään, että mitään yhtenäistä kansanopistolaitosta ei (enää ?) ole. Kansanopistot poikkeavat toisistaan monilla eri ulottuvuuksilla. Eri opistojen omaksumat koulutustehtävät ovat erilaisia. Perinteisen vapaan sivistystyön rinnalle ja ohi on useissa opistoissa noussut eri tavoin toteutettu ammatillinen koulutus. Nyt jo noin parin kymmenen opiston meno mukaan ammattikorkeakoulutoimintaan on entisestään korostanut ammatillisen koulutuksen painokkuutta, tosin tuonut myös uuden kehitystyöhön haastavan koulutustason kansanopistojen yhteyteen. Kymmenissä opistoissa toteutetaan myös monien eri koululainsäädäntöjen alaista koulutusta yhtä aikaa.

\section{Raportin mukaan kansan-} opistot ovat enimmäkseen toteuttaneet ammatillista koulutusta niillä aihealueilla, jotka ovat jo perinteisesti kuuluneet niiden ahvuuksiin vapaana sivistystyönä. Kasvatukselliset aineet, viestintä, taiteet ja humanistinen koulutusala ovat kansanopistojen ammatillisen koulutuksen ydintä. Näin ollen voisi ajatella, että kysymys on omasta perinteestä nousevasta toimialan laajennuksesta ajan muutosten mukana.

\section{Tosin raportissa}

ilmaistaan myös huoli siitä, että eritoten taloudellisista syistä opistot ovat joutunet monin paikoin laajentumaan varsin monille koulutusaloille. Erikoistuminen liian painokkaasti esimerkiksi aikuisten ammatillisen lisäkoulutuksen tai työvoimapoliittisen koulutuksen kaltaisiin, rahoitukseltaan epävarmoihin suuntiin saattaa pidemmässä katsannossa osoittautua kohtalaisen lyhytnäköiseksi ratkaisuksi.

\section{Erilaistuminen opistojen} välillä näkyy myös alueellisesti. Tyhjenevän kehitysalueSuomen opistoista osa on alkanut potea selkeää opiskelijapulaa, jota tosin on pystytty paikkamaan esimerkiksi ottamalla ohjelmaan avoimen yliopiston tarjontaa. Samanaikaisesti suurten väestökeskittymien opistoilla opiskelijoita on riittämiin.

\section{Taustaliikkeiden arvo-} maailmojen paino opistojen työssä on raportin mukaan useimmissa tapauksissa häipynyt olemattomiin. Selkeimmin arvot näkyvät edelleen joidenkin kristillisten ja järjestöopistojen arjessa. Opistoilta on enimmäkseen poistunut myös niille ennen ominainen alueellinen koulutustehtävä. Vapaan sivistystyön laissa korostetaan kansanopistojen sisäoppilaitosluonnetta. Kuitenkin arviointiraportin mukaan 
näyttää siltä, että lain "velvoitetta" tulkitaan joustavasti. Syytkin ovat ymmärrettäviä: toimivan internaatin ylläpito on paitsi pedagogisesti arvokasta, myös kallista. Toisaalta elämäntavan muutokset ja nähtävästi myös koulutuksen välineellisyyden lisääntyminen ovat vähentäneet opiskelijoiden halua asua opistolla. Myös henkilökunnan pyrkimys, varsinkin sukupolvien vaihtuessa, on erottaa työ ja vapaa-aika toisistaan. Opistoissa asuvia opettajia ja rehtoreita on yhä vähemmän.

\section{Opistojen internaatti-} luonteen pysyttämistä vaikeuttaa selkeästi myös rahoituslainsäädännön muutokset. Valtionosuuksien nollasummapelissä pärjää se, joka tekee halvemmalla ja enemmän kuin muut. Ne, joilla on kalliit rakenteet ja rakennukset, häviävät nykysäännöksillä väistämättä pelin siiyä huolimatta, että toiminnan laadukas infrastruktuuri edistäisi kansanopistotyön opetuksellisten ja kasvatuksellisten tavoitteiden saavuttamista.

\section{Omasta mielestäni riskinä}

on myös kansanopistoille ominaisen erityisryhmien palvelemisen ja varsinkin syrjäytymisvaarassa oleville koulutettaville tarkoitetun välttämättömän räätälöinnin ja ohjauksen vähentyminen. Pienten ryhmien ja erityisaiheiden sijasta on jo valtionapumekanismin takia suuntauduttava suuriin ryhmäkokoihin ja "varmoihin nakkeihin".

\section{Raportissa todetaan}

useassa kohdassa se, että opistojen rakennuskannan uhkaava rapautuminen on opistojen tulevaisuudelle suuri uhka.
Jo muutaman vuoden jatkunut tosiasiallinen nollalinja valtion rakennusavustuksissa lisää omarahoituspaineita ja toisaalta myös osaltaan uhkaa kiinteistöistä riippuvaisen sisäoppilaitostoiminnan vetovoimaisuutta.

\section{Lainsäätäjälle raportti}

esittää haasteen kansanopistoa koskevien linjausten tarkentamiseksi. Ongelmia nähdään sisäoppilaitosluonteen määrittelyssä sekä siinä, keille toiminnan pitäisi ensi sijassa kohdentua ja mitä koulutustehtäviä kansanopistojen tulisi toteuttaa. Myös vapaan sivistystyön lähtökohdista tapahtuva rahoitussäädösten uudistaminen nähdään tarpeellisena.

\section{Yleisesti ajateltuna}

raportin valtiovallalle tarjoamat johtopäätökset tuntuvat kyllä linjakkailta. Sisäoppilaitosluonteen kehittäminen olisi voitava turvata mielestäni niille opistolle, jotka siitä ovat kiinnostuneita. Tämä pitäisi tehdä myös taloudellisesti mahdolliseksi. Toisaalta taas internaatin velvoittavuuden ei tulisi koskea opistoja, joiden opiskelijat kuitenkin asuisivat suureksi osaksi tai miltei kokonaan opiston ulkopuolella. Näinhän on laita suurten asutuskeskusten kansanopistoissa.

\section{Kysymys kansanopistojen} koulutustehtävistä ja kohderyhmistä tulisi nähdäkseni jatkossakin ratkaista suomalaisen sivistystyön perinteen "vapaan tehtävänhaun" hengessä. Tämä ei tarkoita sitä nykytilaa, jossa monien opistojen on tehtävä pakon sanelemina vähän sitä sun tätä, jatkuvasti erilaisia rahahanoja etsien. Vapaus on tuosta kaukana.

\section{Näkisin, että yksilön} oman kasvun ja kansalaiskasvatuksen tarpeista lähtevässä monipuolisessa opintotarjonnassa olisi jatkossakin kansanopistojen toiminnan ydin, josta sitten voisi lähteä elinvoimaisia versoja ammatillisen koulutuksen suuntaan. Vapaan sivistyksen tarpeen korostamisen ei tulisi olla jonkin menneen lintukodon haikailua. Ei mennyt palaa. Sovitettuna maailman ja elämäntapojen muuttumiseen ihmisestä itsestä lähtevän kasvun edistäminen vapaan sivistystyön oppilaitoksissa tarjoaisi myös vaihtoehdon muutoin kovin tutkinto- ja suorituskeskeiselle aikuiskoulutukselle.

\section{Vapaan sivistystyön}

toteuttaminen edellyttää kuitenkin sellaista resurssitasoa, jossa laadukas ja ajanmukainen opiskelu on mahdollista. Valtionosuusjärjestelmän tulisi tukea laatua ja kehitystyötä, ei kilpailuttaa opistoja toisiaan vastaan jatkuvissa säästötalkoissa ja suoritekustannusten alentamisessa.

\section{Yhteiskunta voisi myös} tarjota opistoille tehtäviä, jotka kulloinkin nähtäisiin priorisoinnin arvoisiksi. Parlamentaarisen aikuiskoulutustyöryhmän asialistalla ollut huonosti koulutetun aikuisväestön koulutustason nostohanke olisi juuri tällainen kansanopistoille soveltuva ajankohtainen yhteiskunnallinen palvelutehtävä. Tällaiset yhteiskunnan tekemät priorisoinnit eivät olisi opistojen vapaudesta pois, vaan lisäarvoa siihen.

\section{Siitä huolimatta, että} kansanopistot ovat edustaneet tähänkin asti erilaisia traditoita ja arvotaustoja, ne ovat 
kuitenkin muodostaneet enemmän tai vähemmän yhtenäisen pedagogisesta perinteestä nousevan liikkeen. Erilaisuus on yhdistänyt myös siinä mielessä, että arvojen moninaisuus on nähty vapaan sivistystyön kasvupohjaksi ja sen yhteiskunnallisen merkityksen peruspilariksi.

\section{On kuitenkin nähtävissä} mahdollinen kehityskulku, jonka seurauksena olisi opistokentän yhtenäisyyden purkautuminen opistojen erkaantuessa eri tyyppisiä koulutustehtäviä toteuttaviksi ja hyvin erilaisin resurssein toimiviksi ryhmittymiksi. Vaikkapa vahvasti ammattikorkea- koulujen kehitystyössä mukana olevien, kasvukeskuksissa sijaitsevien ja suurten opistojen tulevaisuuden horisontit saattavat sijaita aika etäällä pienten, tyhjenevien maaseutupaikkojen opistojen näköaloista. Käsitys yhteisestä intressistä saattaa tulla yhä ohuemmaksi. Tulevaisuuden polkujen moninaisuus ja erilaisten opistojen etujen ristikkäisyys voi olla vähän paradoksaalisestikin kansanopistotyön vahvin edunvalvonnallinen perusta.

\section{Kaikkiaan arviointi-} raportti toimii hyvänä virikkeenä kansanopistojen toiminnan kehittämisessä. Itse koin raportin kansainvälisen vertailuosan, joissa kerrottiin perustietoja Tanskan, Ruotsin ja Norjan kansanopistoista, melko ohueksi. Pohdiskelu puuttui tyystin. Vertailua ei käytetty mihinkään.

\section{Raportin otsikko oli}

myös vähän turhan raflaava, eikä oikeastaan kovin hyvin linjassa sisällön kanssa. Perinne vaikuttaa varmasti aina siihen, mitä tänään tehdään, mutta puristus tulee kyllä enemmänkin kansanopistojen sijainnista nykyajan ja tulevaisuuden välissä.

PerttiRantanen 